\title{
PENERAPAN MODEL PEMBELAJARAN KOOPERATIF TIPE TEAM ASSISTED INDIVIDUALIZATION (TAI) UNTUK MENINGKATKAN HASIL BELAJAR BIOLOGI PADA KELAS X SMA NEGERI 9 BULUKUMBA
}

\author{
Rahmawati Razak ${ }^{1}$ \\ SMA Negeri 9 Bulukumba
}

\begin{abstract}
ABSTRAK
Penelitian ini untuk mengetahui gambaran pembelajaran Biologi sebelum penerapan model kooperatif Team Assisted Individualization (TAI), untuk mengetahui aktivitas pendidik dalam implementasi model pembelajaran kooperatif tipe Team Assisted Individualization (TAI), untuk mengetahui aktivitas peserta didik dalam implementasi model pembelajaran kooperatif tipe Team Assisted Individualization (TAI), untuk mengetahui peningkatan hasil belajar Biologi peserta didik setelah diimplementasikan model kooperatif tipe Team Assisted Individualization (TAI) dan untuk mengetahui respon peserta didik terhadap kooperatif tipe model Team Assisted Individualization (TAI). Jenis penelitian ini adalah penelitian tindakan kelas (PTK). Dalam Penelitian Tindakan Kelas (PTK) ini meliputi 4 tahap yaitu perencanaan, tindakan, pengamatan (observasi) dan refleksi.Penelitian Tindakan Kelas (PTK) dilaksanakan pada semester genap tahun pelajaran 2018/2019. Subjek penelitian ini adalah peserta didik Kelas X SMA Negeri 9 Bulukumba dengan jumlah peserta sebanyak 21 orang. Adapun instrument yang digunakan dalam penelitian ini adalah Tahap Observasi, Tes/evaluasi, Dokumentasi dan Angket. Berdasarkan hasil observasi penelitian tindakan kelas model pembelajaran kooperatif tipe TAI serta mengacu pada rumusan masalah dalam penelitian ini yang dilaksanakan selama dua siklus, maka peneliti memperoleh kesimpulan dari hasil penelitian tindakan ini. Adapun kesimpulan yang dimaksud dalam penelitian ini adalah meningkatnya aktivitas pendidik ditandai setiap siklus diantaranya pada siklusl pada pertemuan pertama memperoleh skor rata-rata yaitu 50,85 persen pada pertemuan kedua memperoleh skor dengan rata-rata 62,9 persen. Sedangkan pada siklus II mengalami peningkatan yaitu 80 persen, meningkatnya aktivitas peserta didik pada setiap pertemuan dalam penerapan model pembelajaran kooperatif tipe TAI, Meningkatnya hasil belajar peserta didik dalam setiap siklus pembelajaran. Pada siklus I hasil belajar 62,9 persen sedangkan pada siklus II meningkat menjadi 80 persen, dan dengan penerapan model pembelajaran kooperatif tipe TAI meningkatkan hasil belajar peserta didik.
\end{abstract}

Kata kunci: Model Pembelajaran, Kooperatif, Team Assisted Individualization (TAI), Hasil Belajar, Biologi

\section{PENDAHULUAN}

Peningkatan kualitas mutu pendidikan dan pengembangan proses pembelajaran merupakan masalah yang selalu menuntut perhatian. Perbedaan tingkat serap antara peserta didik yang satu dengan yang lainnya terhadap materi pembelajaran menuntut seorang pendidik melakukan inovasi-inovasi dalam pembelajaran sehingga tidak sekedar menyajikan materi, tetapi juga perlu menggunakan metode yang sesuai, disukai dan mempermudah pemahaman peserta didik. 
Dalam proses pendidikan di sekolah, kegiatan belajar mengajar merupakan kegiatan yang paling pokok. Keberhasilan pencapaian tujuan pendidikan terutama ditentukan oleh proses belajar mengajar yang dialami peserta didik. Peserta didik yang belajar akan mengalami perubahan baik dalam pengetahuan, pemahaman, keterampilan, nilai dan sikap.

Berdasarkan hasil observasi pra penelitian yang dilakukan oleh peneliti pada bulan Januari dengan melakukan wawancara langsung dengan siswa, dan mendapatkan informasi bahwa sebenarnya peserta didik kelas IX .5 masih belum mencapai ketuntasan dalam belajar. Namun, karena tuntutan keadaan sehingga peserta didik harus dituntaskan dalam belajar, jika peserta didik tidak mencapai Nilai ketuntasan akan diadakan remedial. Dalam proses pembelajaran juga cenderung terpusat kepada pendidik atau peran pendidik di kelas lebih dominan dibandingkan peserta didik. Ketika pendidik meminta peserta didik mengajukan pertanyaan tentang hal-hal yang tidak mereka pahami, peserta didik tersebut malas bertanya dan hanya diam. Peserta didik juga merasa tidak percaya diri untuk menjawab ataupun memberikan pertanyaan/tanggapan secara terbuka, baik kepada pendidik maupun teman sebayanya.

Secara umum terlihat bahwa peserta didik kurang aktif sehingga peserta didik dalam pembelajaran belum berkembang secara optimal. Salah satu faktor penyebabnya adalah berasal dari dalam diri peserta didik sendiri, peserta didik menganggap bahwa Biologi merupakan pelajaran yang sulit dan mengandung bahasa yang rumit. Selain itu, peserta didik juga tidak termotivasi bekerjasama dengan teman sebayanya saat menyelesaikan soal yang diberikan pendididk. Hal ini terlihat dari kurangnya aktifitas pendidik berdiskusi dengan temannya untuk mengerjakan tugas yang diberikan pendidik. Beberapa peserta didik tertentu saja yang mengerjakan tugas yang diberikan oleh pendidik, sedangkan peserta didik yang lain menunggu pekerjaan temannya selesai agar dapat mencontoh, bahkan ada juga yang tidak mengerjakan tugas sama sekali. Masalah ini jika dibiarkan berlanjut akan berakibat kepada aktivitas dan hasil belajar yang diperoleh peserta didik.

Peranan pendidik sangat dibutuhkan untuk membantu peserta didik aktif dalam proses pembelajaran. Diperlukan sebuah pendekatan yang lebih memperdayakan peserta didik yang harus memiliki peran yang lebih banyak dibandingkan dengan pendidik. Pendidik hanya sebagai fasilitator dalam pembelajaran.

Keterlibatan peserta didik dalam kegiatan pembelajaran dan pelaksanaan pembelajaran yang menyenangkan diharapkan dapat meningkatkan hasil belajar peserta didik. Hasil belajar peserta didik yang meningkat diharapkan juga dapat meningkatkan kualitas pendidikan.

Pendidik merupakan salah satu faktor yang mempunyai peranan yang sangat penting dalam keberhasilan pembelajaran. Salah satu kemampuan yang harus dimiliki oleh pendidik adalah mampu memilih metode atau model pembelajaran yang dapat menciptakan suasana dan iklim belajar yang dapat memotivasi pendidik dalam belajar. Untuk mengatasi permasalahan tersebut, salah satu alternatif yang bisa ditempuh oleh pendidik adalah hendaknya mengkaji ulang beberapa metode yang digunakan dalam proses pembelajaran.

Salah satu alternatif untuk mengatasi masalah yang ada yaitu berupa penerapan model pembelajaran yang lebih mengutamakan keaktifan peserta didik dan memeberikan kesempatan peserta didik untuk mengembangkan potensinya secara maksimal. Model pembelajaran yang dimaksudkan adalah model pembelajaran kooperatif. Dalam pelaksanaannya pembelajaran kooperatif dapat merubah peran pendidik dari peran terpusat pada pendidik menjadi peran pengelola aktivitas 
kecil. Sehingga peran pendidik yang selama ini menoton akan berkurang dan peserta didik akan terlatih untuk menyelesaikan berbagai permasalahan dalam pembelajaran.

Dalam model pembelajaran kooperatif terdapat beberapa tipe, salah satunya adalah model pembelajaran TAI (Team Assisted Individualization) yang dapat diterapkan dalam pembelajaran Biologi. Dengan mempertimbangkan hasil penelitian yang dilakukan oleh peneliti dan salah satunya yang dilakukan oleh Raidah Muharrikah, (2011) Mahasiswa Universitas Negeri Makassar Fakultas Matematika Dan Ilmu Pengetahuan Alam dengan judul Meningkatkan Hasil Belajar Melalui Model Pembelajaran Kooperatif Tipe Team Assisted Individualization (TAI) Pada Siswa kelas VII $\mathrm{B}_{2}$ SMP Islam Terpadu Islamiyah Makassar mendapatkan hasil bahwa hasil belajar Biologi pengalami peningkatan dan pesera didik juga temotivasi dalam belajar. Oleh karena itu, Peneliti juga memilih model pembelajaran yang sama yaitu model pembelajaran kooperatif tipe Team Assisted Individualization (TAI) sehingga peserta didik dapat memahami sepenuhnya pembelajaran Biologi. Peserta didik dapat lebih aktif dalam proses pembelajaran dan pelajaran Biologi dapat menjadi pelajaran yang menyenangkan untuk dipelajari.

Menurut Rustam (2013:404), "Model pembelajaran kooperatif Team Assisted Individualization (TAI) menggabungkan kegiatan pembelajaran kooperatif dan pengajaran individual". Peserta didik dalam kelompok dituntut untuk melakukan kerja sama dalam memecahkan masalah materi pembelajaran dalam hal ini kesulitan. Melalui model pembelajaran ini, peserta didik dituntut untuk aktif, dan interaksi peserta didik dengan pendidik maupun peserta didik dengan peserta didik lebih dapat ditingkatkan dan mempermudah peserta didik dalam menyelesaikan soal-soal pembelajaran yang dapat meningkatkan hasil belajar peserta didik.

\section{KAJIAN PUSTAKA}

\section{Hasil Belajar Biologi}

Dari semua rangkaian kegiatan pembelajaran yang dilaksanakan maka peserta didik diharapakan dapat mencapai hasil yang maksimal dan memuaskan. Dari proses belajar peserta didik senantiasa ingin mencapai hasil yang baik dari kegiatan belajarnya, demikian pula pendidik sebagai pendidik ingin memperoleh hasil belajar yang maksimal untuk peserta didiknya.

Menunurut Kaller dalam Abdurrahman (1999:14) hasil belajar adalah "prestasi aktual yang ditampilkan anak, belajar dipengaruhi oleh besarnya usaha (perbuatan yang terarah pada penyelesaian tugas-tugas belajar) yang dilakukan oleh anak". Sudjana dalam Muharrikah (2011:10) menyatakan hasil belajar adalah "kemampuan yang dimiliki siswa setelah menerima pengalaman".

Menurut Bloom dalam Sudijono (2011:49) mengemukakan bahwa taksonomi (pengelompokan) tujuan pendidikan itu harus mengacu kepada 3 jenis domain (ranah) yaitu ranah kognitif, afektif, dan psikomotor.

\section{a. Ranah Kognitif}

Ranah kognitif adalah ranah yang mencakup kegiatan mental (otak). Dalam ranah kognitif itu terdapat enam jenjang proses berpikir, mulai dari jenjang terendah sampai jenjang yang paling tinggi. Keenam jenjang dimaksud adalah pengetahuan/hafalan/ingatan, pemahaman, penerapan, analisis, sintesis, dan penilaian. Dalam proses pembelajaranBiologipada materi kebijakan pemerintah dibidangBiologidalam ranah kognif aspek yang dinilai adalah pemahaman, pengetahuan, penerpan, pemecahan masalah dan analisis peserta didik tentang pengertian teoriBiologimikro danBiologimakro, serta masalah-masalah yang dihadapi pemerintah dalam bidang ekonomi.

b. Ranah Afektif

Ranah afektif adalah ranah yang berkaitan dengan sikap dan nilai. Ciri-ciri 
hasil belajar afektif akan tampak pada peserta didik dalam berbagai tingkah laku. Ranah afektif ini oleh Krathwohl dalam Sanjaya (2008:128) dan kawan-kawan ditaksonomi (pengelompokan) menjadi lebih rinci lagi ke dalam lima jenjang, yaitu receiving (menerima atau memperhatikan), responding (menanggapi), valuing (menilai=menghargai), organization (mengatur atau mengorganisasikan), dan characterization by a value or value complex (karakterisasi dengan suatu nilai atau komplek nilai). Dalam pembelajaran Biologikhusus pada materi kebijakan pemerintah dibidang Biologi aspek yang dinilai pada ranah afektif terbagi atas tiga yaitu: sikap aktif, sikap bekerjasama, dan tingkah laku pesera didik.

\section{c. Ranah Psikomotor}

Ranah psikomotor adalah ranah yang berkaitan dengan keterampilan (skill) atau kemampuan bertindak setelah seseorang menerima pengalaman belajar tertentu.Hasil belajar psikomotorik ini sebenarnya merupakan kelanjutan dari hasil belajar kognitif (memahami sesuatu) dan hasil belajar afektif (yang baru tampak dalam bentuk kecendrungan-kecendrungan untuk berprilaku. Hasil belajar kognitif dan hasil belajar akan menjadi hasil belajar psikomotorik apabila peserta didik telah menunjukkan perilaku atau perbuatan tertentu sesuai dengan makna yang terkandung dalam ranah kognitif dan ranah afektifnya. Dalam pembelajanBiologipada materi kebijakan pemerintah dibidang ekonomi.

Dari definisi para ahli diatas maka pengertian hasil belajar Biologi adalah hasil akhir yang dicapai peserta didik melalui pengukuran keterampilan, pengetahuan dan kemajuan belajar Biologi dalam waktu tertentu.

\section{Pembelajaran Kooperatif (Cooperative Learning)}

Dalam model pembelajaran kooperatif ini, pendidik lebih berperan sebagai fasilitator yang berfungsi sebagai jembatan penghubung kearah pemahaman yang lebih tinggi, dengan catatan peserta didik itu sendiri. Pembelajaran kooperatif (cooperative learning) merupakan bentuk pembelajaran dengan cara peserta didik belajar dan bekerja dalam kelompokkelompok kecil secara kolaboratif yang anggotanya terdiri dari empat sampai enam orang dengan srtuktur yang bersifat heterogen. Dalam pembelajaran ini akan tercipta sebuah interaksi yang lebih luas, yaitu interaksi dan komunikasi yang dilakukan antara pendidik dengan peserta didik, peserta didik dengan peserta didik dan peserta didik dengan pendidik (multi way traffic communication).

Sanjaya dalam Rustam, (2013:203) mengemukakan bahwa Cooperative learning merupakan kegiatan belajar peserta didik yang dilakukan dengan cara kelompok. Model pembelajaran kelompok adalah rangkaian kegiatan belajar yang dilakukan oleh peserta didik dalam kelompokkelompok tertentu untuk mencapai tujuan pembelajaran yang telah dirumuskan.

Johnson dalam Rustam, (2013:201) mengemukakan bahwa Cooperative Learning adalah teknik pengelompokan yang didalamnya peserta didik bekerja terarah pada tujuan belajar bersama dalam kelompok kecil yang umumnya terdiri dari 4-6 orang. Belajar cooperative adalah pemanfaatan kelompok kecil dalam pembelajaran yang memungkinkan peserta didik bekerja sama untuk memaksimalkan belajar mereka dan belajar anggota lainnya dalam kelompok terasebut.

Sanjaya, (2008:42) Pembelajaran kooperatif akan efektif digunakan apabila:

(1) pendidik menekankan pentingnya usaha bersama di samping usaha secara individual, (2) pendidik menghendaki pemerataan 
perolehan hasil dalam belajar, (3) pendidik ingin menanamkan tutor sebaya atau belajar melalui teman sendiri, (4) pendidik menghendaki adanya pemerataan partisipasi aktif siswa, (5) pendidik menghendaki kemampuan siswa dalam memecahkan berbagai permasalahan.

\section{Model kooperatif Tipe Team Assisted Individualization (TAI)}

Salah satu model pembelajaran koperatif adalah model pembelajaran Team Assisted Individualization (TAI) yang diprakarsai oleh Robert Slavin. Bentuk pembelajaran ini merupakan kombinasi antara pembelajaran kooperatif/kolaboratif dengan pembelajaran individual. Metode ini memperhatikan perbedaan pengetahuan awal tiap peserta didik untuk mencapai prestasi belajar. Pembelajaran individual dipandang perlu diaplikasikan karena peserta didik memasuki kelas dengan pengetahuan, kemampuan, dan motivasi yang berbeda-beda. Saat pendidik mempresentasikan materi pembelajaran, tentunya ada sebagian peserta didik yang tidak memiliki pengetahuan prasyarat untuk mempelajari materi tersebut. Ini tentu dapat menyebabkan peserta didik yang tidak memiliki pengetahuan prasyarat itu akan gagal mencapai tujuan pembelajaran yang diharapkan pendidik. Bagi peserta didik lain, mungkin sudah menguasai materi pembelajaran itu.

Menurut Huzaifah (2013). Dengan perpaduan antara pembelajaran kooperatif dan individual dapat diperoleh dua keuntungan sekaligus, yaitu :

1. Siswa yang lemah dapat terbantu dalam menyelesaikan masalahnya;

2. Siswa yang pandai dapat mengembangkan kemampuan dan keterampilannya;

3. Adanya tanggung jawab dalam kelompok dalam menyelesaikan permasalahannya;

4. Siswa diajarkan bagaimana bekerjasama dalam suatu kelompok.
Menurut Fariq (2013). Kelompok heterogen digunakan dalam penerapan msodel pembelajaran kooperatif tipe TAI (Team Assisted Individualization atau Team Accelerated Instruction) karena beberapa alasan, yaitu :

a) Kelompok heterogen memberikan kesempatan untuk saling mengajar melalui tutor sebaya (peer tutoring) dan saling mendukung.

b) Kelompok heterogen meningkatkan hubungan dan interaksi antar peserta didik walaupun berbeda ras, agama, etnik, dan gender

c) Kelompok heterogen memudahkan pengelolaan kelas karena pada setiap kelompok terdapat peserta didik yang memiliki kemampuan akademis bagus, dengan demikian secara tidak langsung pendidik mendapatkan bantuan mengajar untuk peserta didik lain yang berada di dalam kelompok yang sama. Kunci model pembelajaran kooperatif yang menggunakan tipe Team Assisted Individualization adalah penerapan bimbingan antar teman.

Menurut Mardia (2004:13) Model pembelajaran tipe TAI ini memiliki 8 komponen, kedelapan komponen tersebut adalah sebagai berikut :

1. Teams yaitu pembentukan kelompok heterogen yang terdiri dari 4 sampai 6 peserta didik

2. PlacementTest yaitu pemberian pre test kepada peserta didik atau melihat rata-rata nilai harian peserta didik agar pendidik mengetahui kelemahan peserta didik pada bidang tertentu.

3. StudentCreative yaitu melaksanakan tugas dalam suatu kelompok dengan menciptakan dimana keberhasilan individu ditentukan oleh keberhasilan kelompoknya.

4. TeamStudy yaitu tahapan tindakan belajar yang harus dilaksanakan oleh kelompok dan pendidik memberikan 
bantuan secara individual kepada peserta didik yang membutuhkan.

5. TeamScore and TeamRecognition yaitu pemberian score terhadap hasil keja kelompok dan memberikan kriteria penghargaan terhadap kelompok yang berhasil secara cemerlang dan kelompok yang dipandang kurang berhasil dalam menyelesaikan tugas.

6. TeachingGroup yaitu pemberian materi secara singkat dari pendidik menjelang pemberian tugas kelompok.

7. Facttest yaitu pelaksanaan tes-tes kecil berdasarkan fakta yang diperoleh peserta didik

8. Whole-Class Units yaitu pemberian materi oleh pendidik kembali di akhir waktu pembelajaran dengan strategi pemecahan masalah.

\section{METODE PENELITIAN}

Jenis penelitian ini adalah penelitian tindakan kelas (PTK). Penelitian tindakan kelas dilakukan sebagai upaya pemecahan masalah dan peningkatan kualitas pendidikan. Penelitian Tindakan Kelas merupakan suatu jenis penelitian yang dilakukan oleh pendidik untuk memecahkan permasalahan dalam kelasnya. Penelitian ini bertujuan untuk memberikan gambaran tentang peningkatan-peningkatan hasil belajar peserta didik melalui penerapan model pembelajaran kooperatif tipe (TAI) Team assisted Individualization. Dalam Penelitian Tindakan Kelas (PTK) ini meliputi 4 tahap yaitu perencanaan, tindakan, pengamatan (observasi) dan refleksi.

Fokus Penelitian ini adalah penerapan model pembelajaran kooperatif tipe Team Assisted Individualization (TAI) untuk meningkatkan hasil belajar Biologi pada materi memupuk budi pekerti bagi peserta didik Kelas X SMA Negeri 9 Bulukumba. Penelitian Tindakan Kelas (PTK) dilaksanakan pada semester genap tahun pelajaran 2018/2019. Subjek penelitian ini adalah peserta didik Kelas X SMA Negeri 9 Bulukumba dengan jumlah peserta sebanyak 21 orang.

Adapun instrument yang digunakan dalam penelitian ini adalah Tahap Observasi, Tes/evaluasi, Dokumentasi dan Angket. Pengelolaan data dalam penelitian ini menggunakan teknik analisis deskriptif kualitatif, yaitu suatu metode penelitian yang bersifat menggambarkan kenyataan atau fakta sesuai dengan data yang diperoleh dengan tujuan untuk mengetahui prestasi belajar yang dicapai peserta didik juga memperoleh respon peserta didik terhadap kegiatan pembelajaran serta aktivitas peserta didik selama pembelajaran.

Indikator keberhasilan pelaksanaan penelitian ini adalah apabila terjadi peningkatan skor rata-rata hasil belajar Biologi dan perubahan aktivitas peserta didik terhadap bahan ajar setelah diberiakan pembelajaran kooperatif tipe TAI. Selain itu, peserta didik harus mencapai nilai KKM yaitu 70

\section{HASIL PENELITIAN DAN \\ PEMBAHASAN}

\section{Hasil Penelitian}

\section{a. Data Sebelum Tindakan}

Pada bagian ini akan dipaparkan hasil penelitian yang dilakukan di Kelas X SMA Negeri 9 Bulukumba dengan menggunakan model pembelajaran kooperatif tipe TAI. Adapun paparan data penelitian mencakup; paparan data sebelum tindakan, paparan data siklus I, dan paparan data siklus II. Hal ini dilakukan untuk mengetahui perkembangan alur setiap tindakan.

Sebelum peneliti melakukan tindakan yaitu terlebih terdahulu peneliti mengamati pendidik dalam pelajaran Biologi terdapat beberapa hal-hal yang diamati yaitu pada aspek penjelasan materi peneliti menilai pendidik cukup dalam menjelaskan materi pembelajaran penerapan kebiasaan bertanya dinilai kurang karena pendidik hanya 
memberikan penjelasan materi tanpa diimbangi dengan memberikan kesempatan bertanya kepada peserta didik dan tidak mengadakan tanya jawab. Aspek dari segi teknik pemberian pembelajaran juga dinilai kurang dikarenakan pendidik hanya menjelaskan materi tanpa melibatkan peserta didik secara aktif dalam pembelajaran.

Setelah peneliti mengamati aktivitas pendidik, selanjutnya peneliti mengadakan tes awal (Pre-Test) untuk mengetahui hasil belajar atau untuk mengetahui rata-rata belajar peserta didik dengan memberikan soal-soal yang telah dipelajari sebelumnya. Setelah tes awal diberikan, didapatkan hasil sebagai berikut:

Adapun deskripsi nilai hasil belajar Biologi peserta didik pada tes awal dapat dilihat pada tabel 1 berikut:

Tabel 1 Deskripsi hasil belajar Biologi peserta didik Kelas X SMA Negeri 9 Bulukumba pada Tes Awal

\begin{tabular}{cc}
\hline Statistik & Nilai statistik \\
\hline Subjek peneitian & 21 \\
Skor ideal & 100 \\
Skor rata-rata & 50,85 \\
Skor maksimal & 85 \\
Skor minimum & 40 \\
\hline
\end{tabular}

Sumber : Hasil Analisis Lampiran E.1

Berdasarkan tabel 1 menunjukkan bahwa skor rata-rata hasil belajarBiologipeserta didik Kelas X SMA Negeri 9 Bulukumba pada tes awal sebesar 50,85 dari skor ideal yaitu 100. Skor maksimum yang dicapai adalah 40 dan skor maksimal 85, berarti rentang skor peserta didik yaitu 45. Selanjutnya, diperoleh distribusi frekuensi dan presentase skor hasil belajar Biologipeserta didik pada tes awal yang dapat dilihat pada tabel 2 berikut ini:

Tabel. 2 Distribusi frekuensi dan presentase skor hasil belajar peserta didik kelas Kelas X SMA Negeri 9 Bulukumba pada tes awal

\begin{tabular}{|c|c|c|c|}
\hline $\begin{array}{c}\text { Interval } \\
\text { nilai }\end{array}$ & Kategori & Frekuensi & Presentase \\
\hline
\end{tabular}

\begin{tabular}{cccc}
\hline$<55$ & Sangat & 10 & 47,61 \\
$55-65$ & Rendah & 2 & 9,52 \\
$66-79$ & Rendah & 4 & 19,04 \\
$80-89$ & Sedang & 4 & 19,04 \\
$90-100$ & Tinggi & 1 & 4,76 \\
& Sangat & & \\
\hline & Tinggi & & 100,00
\end{tabular}

Sumber: Hasil Analisi lampiran E.1

Berdasarkan data diatas, dalam kategori sangat rendah sebanyak 10 peserta didik, dalam kategori rendah sebanyak 2 peserta didik, dalam kategori sedang sebanyak 4 orang sedangkan dalam kategori tinggi 1 orang peserta didik yang mencapai kategori tersebut.

Tabel. 3 Deskriptif ketuntasan hasil tes awal peserta didik Kelas X SMA Negeri 9 Bulukumba

\begin{tabular}{|c|c|c|c|}
\hline Skor & Kategori & Frekuensi & Persentase $\%$ \\
\hline $0-69$ & $\begin{array}{l}\text { Tidak } \\
\text { tuntas }\end{array}$ & 16 & 76,19 \\
\hline $70-100$ & Tuntas & 5 & 23,80 \\
\hline \multicolumn{2}{|c|}{ Jumlah } & 21 & 100,00 \\
\hline
\end{tabular}

Sumber: Hasil Analisis Lampiran E1

Dilihat dari data diatas dapat disimpulkan bahwa, peserta didik belum bisa memahami materi yang disampaikan oleh pendidik dengan metode yang digunakan selama ini. Dari 22 orang peserta didik yang mengikuti tes awal, hanya 5 orang yang mendapatkan nilai di atas standar kriteria ketuntasan minimal dengan presentase 23,80 persen sedangkan peserta didik yang tidak tuntas sebanyak 16 peserta didik dengan presentase 76,19 persen. Oleh karena itu, pembelajaran perlu ditingkatkan dalam pelaksanaan siklus.

\section{a. Data Tindakan Silkus 1}

\section{1) Tahapan Perencanaan Siklus I}

Untuk memudahkan peneliti, dalam penelitian maka terlebih dahulu peneliti menelaah atau mempelajari kurikulum yang digunakan dalam sekolah Kelas X SMA Negeri 9 Bulukumba. Hal tersebut dilakukan untuk mengetahui dan dapat mencapai standar Kempetensi yang akan dipelajari dalam mata pelajaran Biologi. 
Setelah peneliti mengetahui standar kompetensi dan kompetensi dasar yang akan diterapkan dalam penelitian maka peneliti membuat Rencana Pelaksanaa Pembelajaran (RPP), Lembar Kerja Siswa (LKS), membuat lembar observasi atau lembar pengamatan untuk mengetahui suasana belajar peserta didik dan suasana dalam kelas. Peneliti juga membuat atau menyeleksi soal-soal yang akan diberikan kepada peserta didik selama pembelajaran berlangsung dengan menggunakan model pembelajaran kooperatif Team Assistend Individualization. Sebelum menerapakan model pembelajaran kooperatif Team Assistend Individualization.

\section{2) Tahapan Pelaksanaan Tindakan Siklus} 1

Pelaksanaan tindakan siklus 1 berlangsung selama 3 kali pertemuan, dalam satu kali pertemuan waktu yang digunakan adalah $2 \mathrm{x}$ 45 menit. Pembelajaran siklus 1 berlangsung selama 90 menit. Pada pertemuan pertama pembelajaran Biologi dihadiri oleh 19 peserta didik dari 21 jumlah peserta didik kelasIX5 karena ada 4 orang yang tidak hadir setelah dikomfirmasi dari ketua kelas peserta didik yang tidak hadir tersebut tanpa pemberitahuan sebelumnya atau tanpa keterangan. Pada pertemuan kedua peserta didik yang hadir sebanyak 19 orang dari 21 peserta didik. Dalam proses pembelajaran dibagi dalam tiga tahapan kegiatan yaitu: (1) kegiatan awal, (2) kegiatan inti dan (3) kegiatan akhir.

\section{1) Kegiatan Awal}

Adapun tindakan awal yang dilakukan di Kelas X SMA Negeri 9 Bulukumba sebelum memulai pelajaran ketua kelas menyiapkan kelas untuk berdoa bersama. Setelah itu pendidik mengabsen kehadiran peserta didik. Pendidik menjelaskan tujuan pembelajaran serta materi yang akan dipelajari. Pada pertemuan pertama pendidik menjelaskan materi disesuaikan dengan model pembelajaran yang akan digunakan. Dalam pembelajaran tersebut diguanakan model pembelajaran kooperatif tipe Team Assisted Individualization (TAI).

2) Kegiatan Inti

Sesuai dengan langkah-langkah model pembelajaran TAI yaitu terlebih dahulu peneliti menjelaskan secara singkat materi yang akan dipelajari. Pendidik melihat banyak peserta didik yangt tidak memperhatikan materi yang disampaikan dengan serius, ada peserta didik yang berbicara dengan teman sebangkunya. Bahkan ada peserta didik yang hanya mengkhayal dan tidak memperhatikan pelajaran.

Setelah menjelaskan materi pembelajaran peneliti membagi peserta didik menjadi beberapa kelompok secara heterogen, dalam satu kelompok terdapat 5-6 orang peserta didik dan kelompok yang dibentuk sebanyak 4 kelompok. Setelah membagi kelompok pendidik meminta peserta didik untuk bergabung dengan anggota kelompoknya masing-masing. Pendidik menekankan bahwa keberhasilan kelompok ditentukan oleh keberhasilan individu, dan apabila ada peserta didik yang tidak mengerti maka peserta didik tersebut bisa meminta bantuan dari temannya atau kepada peneliti. Selanjutnya, setiap peserta didik atau setiap anggota kelompok mengerjakan soal LKS yang telah dibagikan. Selama peserta didik melaksanakan kerja kelompok peneliti juga mengamati secara individu dan pengamatan secara kelompok. Setelah peserta didik mengerjakan soal LKS yang diberikan kemudian peserta didik diminta untuk mengumpulkan LKS sesuai dengan kelompoknya masing-masing. Peneliti meminta satu kelompok secara acak untuk mempresentasikan hasil kerja kelompoknya yang diwakili oleh satu peserta didik dalam kelompoknya. Kelompok tersebut kemudian membacakan hasil kerja kelompoknya dan kelompok yang lain diminta untuk menanggapi jawaban dari kelompok yang mempresentasikan hasil kerja kelompok tersebut. Kelompok penyaji berdiskusi untuk 
memberikan jawaban kepada kelompok yang menanggapi atau yang bertanya.

Peneliti mengarahkan peserta didik apabila terjadi perbedaan pendapat, pada akhir diskusi peserta didik diminta untuk memberikan kesimpulan hasil diskusi yang telah dilaksanakan. Tidak lupa pendidik memberikan pujian kepada kelompok yang telah mempresentasikan hasil keja kelompoknya, bentuk penghargaan yang diberikan peneliti adalah tepuk tangan meriah, acungan jempol dan nilai tambahan dan sebagainya.

Pelaksanaan pembelajaran dengan menggunakan model pembelajaran TAI agar tujuan pembelajaran tercapai sesuai dengan rencana pembelajaran yang dibuat sebelumnya. Setelah diskusi selesai peserta didik diminta untuk mengerjakan LKS secara individu. Selama mengerjakan tugas individu peserta didik biasa bertanya kepada peneliti atau temannya.

\section{3) Kegiatan Akhir}

Pada kegiatan akhir pembelajaran peneliti meminta tanggapan peserta didik mengenai model pembelajaran yang digunakan. Peneliti memberikan penguatan bahwa pentingnya belajar Biologi dan pelajaran yang lain dipelajari. Peneliti memberikan informasi mengenai pelajaran pada pertemuan berikutnya yang akan dipelajari dan meminta peserta didik untuk menyimpulkan hasil belajar Biologi pada akhir pertemuan. Pembelajaran diakhiri dengan ketua kelas memimpin kelas untuk berdoa bersama dan memberikan salam.

Untuk mengetahui keberhasilan pada siklus I diadakan tes evaluasi hasil belajar siklus I dalam bentuk essay sebanyak 5 butir terdapat pada lampiran B.6.

\section{3) Hasil Observasi dan Evaluasi Siklus 1}

\section{(1) Observasi}

Aktivitas peserta didik dalam pelaksanaan siklus 1 pertemuan pertama dan pertemuan ke II selama proses belajar mengajar berlangsung dalam tindakan yang dilakukan dengan menggunakan lembar observasi aktivitas peserta didik dapat dilihat pada tabel dibawah ini:

Tabel 4 Perkembangan aktivitas peserta didik kelas $\mathrm{IX}_{5}$ pada siklus I pertemuan I dan II

\begin{tabular}{|c|c|c|c|}
\hline \multirow[b]{2}{*}{ No. } & \multirow[b]{2}{*}{ Indikator Yang Diamati } & \multicolumn{2}{|c|}{ Siklus I } \\
\hline & & $\begin{array}{l}\text { Pertemuan } \\
\text { I }\end{array}$ & $\begin{array}{l}\text { Pertemuan } \\
\text { II }\end{array}$ \\
\hline 1. & $\begin{array}{l}\text { Peserta didik yang hadir } \\
\text { dalam proses belajar } \\
\text { mengajar }\end{array}$ & 18 & 20 \\
\hline 2. & $\begin{array}{l}\text { Peserta didik yang yang } \\
\text { mengajukan pertanyaan }\end{array}$ & 2 & 3 \\
\hline 3. & $\begin{array}{l}\text { Peserta didik yang aktif } \\
\text { bekerja sama dalam } \\
\text { kelompoknya }\end{array}$ & 7 & 12 \\
\hline 4. & $\begin{array}{l}\text { Peserta didik yang } \\
\text { merespon pertanyaan } \\
\text { yang diajukan } \\
\text { pendidik/peneliti }\end{array}$ & 2 & 3 \\
\hline 5. & $\begin{array}{l}\text { Peserta didik yang } \\
\text { mengerjakan tugas } \\
\text { individu }\end{array}$ & 18 & 20 \\
\hline 6. & $\begin{array}{l}\text { Peserta didik yang } \\
\text { memiliki kemampuan } \\
\text { menyimpulkan materi } \\
\text { pelajaran }\end{array}$ & 1 & 3 \\
\hline 7. & $\begin{array}{l}\text { Peserta didik yang } \\
\text { mengemukakan pendapat }\end{array}$ & 2 & 4 \\
\hline 8. & $\begin{array}{l}\text { Peserta didik yang } \\
\text { melakukan kegiatan lain } \\
\text { seperti ribut, bermain dan } \\
\text { lain-lain }\end{array}$ & 11 & 8 \\
\hline
\end{tabular}

Sumber: Hasil Lampiran B.8 dan B.9

Jumlah peserta didik yang hadir dalam proses belajar mengajar pada pertemuan pertama sebanyak 18 orang. Peserta didik yang mengajukan pertanyaan pertemuan pertama hanya 2 orang. Peserta didik yang aktif bekerja sama dalam kelompok diskusi sebanyak 7 orang. Peserta didik yang merespon pertanyaan yang diajukan oleh pendidik pertemuan pertama sebanyak 2 orang. Adapun peserta didik yang aktif mengerjakan tugas individu pertemuan pertama sebanyak 18 orang. Adapun peserta didik yang memiliki kemampuan menyimpulkan materi pembelajaran sebanyak 1 orang. Sedangkan peserta didik yang mengemukakan pendapat pada peretemuan pertama sebanyak 2 orang, 
disebabkan peserta didik masih canggung untuk mengemukakan pendapat karena peserta didik belum akrab dengan pendidik dan belum terlalu memahami model pembelajaran TAI. Adapun peserta didik yang melakukan kegiatan lain seperti ribut, bermain dan kegiatan lainnya yakni sebanyak 11orang.

Sedangkan dalam pertemuan kedua Jumlah peserta didik yang hadir dalam proses belajar mengajar pada pertemuan kedua sebanyak 20 orang. Peserta didik yang mengajukan pertanyaan pertemuan kedua 3 orang. Peserta didik yang aktif bekerja sama dalam kelompok diskusi sebanyak 12 orang. Peserta didik yang merespon pertanyaan yang diajukan oleh pendidik pertemuan kedua sebanyak 3 orang. Adapun peserta didik yang aktif mengerjakan tugas individu pertemuan kedua sebanyak 20 orang. Adapun peserta didik yang memiliki kemampuan menyimpulkan materi pembelajaran sebanyak 3 orang. Sedangkan peserta didik yang mengemukakan pendapat pada pertemuan kedua sebanyak 4 orang, disebabkan peserta didik masih mulai berani mengemukakan pendapat karena peserta didik sudah mulai akrab dengan pendidik dan sudah mulai memahami model pembelajaran TAI. Adapun peserta didik yang melakukan kegiatan lain seperti ribut, bermanin dan kegiatan lainnya mengalami penurunan yakni sebanyak 8 orang.

Adapun aktivitas pendidik dalam siklus 1 pertemuan pertama dan pertemuan kedua dapat dilihat pada tabel dibawah ini:

Tabel 5 Perkembangan aktivitas pendidik pada mata pelajaran Biologi pada siklus I pertemuan I dan pertemuan II

\begin{tabular}{|c|c|c|c|}
\hline \multirow[b]{2}{*}{ No } & \multirow{2}{*}{$\begin{array}{l}\text { Komponen yang } \\
\text { diamati }\end{array}$} & \multicolumn{2}{|c|}{ Kategori } \\
\hline & & $\begin{array}{l}\text { Pertemuan } \\
\text { I }\end{array}$ & $\begin{array}{l}\text { Pertemuan } \\
\text { II }\end{array}$ \\
\hline 1 & Apersepsi & Cukup & Cukup \\
\hline 2 & Penjelasan materi & Cukup & Cukup \\
\hline 3 & $\begin{array}{l}\text { Penjelasan model } \\
\text { TAI }\end{array}$ & Baik & Baik \\
\hline 4 & $\begin{array}{l}\text { Teknik pembagian } \\
\text { kelompok }\end{array}$ & Baik & Baik \\
\hline
\end{tabular}

\begin{tabular}{|c|c|c|c|}
\hline 5 & $\begin{array}{l}\text { Pengelolaan kegiatan } \\
\text { diskusi }\end{array}$ & Cukup & Baik \\
\hline 6 & $\begin{array}{l}\text { Pemberian } \\
\text { pertanyaan atau kuis }\end{array}$ & Cukup & Cukup \\
\hline 7 & $\begin{array}{l}\text { Kemampuan } \\
\text { melakukan evaluasi }\end{array}$ & Cukup & Cukup \\
\hline 8 & $\begin{array}{l}\text { Memberikan } \\
\text { penghargaan individu } \\
\text { atau kelompok }\end{array}$ & Baik & Baik \\
\hline 9 & $\begin{array}{l}\text { Menyimpulkan } \\
\text { materi pelajaran }\end{array}$ & Cukup & Cukup \\
\hline 10 & Menutup pelajaran & Cukup & Cukup \\
\hline & Presentase & 76,66 & 80,00 \\
\hline
\end{tabular}

Sumber: Hasil Analisis Lampiran B.10 dan B.11

Pada pertemuan pertama dan pertemuan kedua apersepsi pendidik berada pada taraf cukup yang diamati oleh pengamat hal ini disebabkan karena peneliti masih terbiasa dengan suasana kelas. Penjelasan materi pelajaran pada pertemuan pertama dan pertemuan kedua berada dalam kategori cukup karena pendidik masih canggung dan kurang beradaptasi dengan situasi dan kondisi kelas penjelasan model pembelajaran TAI sudah baik tapi masih banyak peserta didik yang ribut dan melakukan kegiatan lain seperti tidak mendengarkan penjelasan pendidik/peneliti dengan serius pada saat pendidik menjelaskan materi. Cara pendidik membagi kelompok yaitu dengan cara heterogen dalam siklus pertama ini dibentuk 4 kelompok, dimana dalam satu kelompok terdiri dari 5-6 orang.

Setelah bergabung dengan anggota kelompoknya pendidik membagikan lembar kerja yang berisi pertanyaan yang akan didiskusikan oleh setiap kelompok. Peneliti mengawasi jalannya diskusi. Pendidik meluruskan jawaban-jawaban peserta didik yang belum sempurna dan sebelum menutup pelajaran pendidik menyimpulkan materi diskusi pada saat itu.

Berdasarkan hasil pengamatan aktivitas pendidik pada siklus I pertemuan pertama dengan presentase 76,66 persen sedangkan pada pertemuan kedua mengalami peningkatan yaitu dengan presentase yang diperoleh adalah 80 persen. 


\section{(2) Evaluasi}

Pada akhir siklus I dilakukan tes hasil belajar yang berbentuk essai yang terdiri dari 5 nomor, adapun analisis deskriptif skor perolehan hasil belajar peserta didik setelah penerapan model pembelajaran TAI dapat dilihat pada tabel berikut:

Tabel 6 Deskriptif skor hasil belajar Biologi peserta didik pada siklus I

\begin{tabular}{cc}
\hline Statistik & Nilai statistik \\
\hline Subjek penelitian & 21 \\
Skor ideal & 100 \\
Skor rata-rata & 62,9 \\
Rentang skor & 55 \\
Skor maksimum & 85 \\
Skor minimum & 30
\end{tabular}

Sumber : Hasil Analisis Lampiran E.I

Pada tabel diatas menunjukkan bahwa, skor rata-rata yang dicapai adalah 62,9 persen dengan skor ideal 100. Adapun skor maksimal yang dicapai pada siklus I adalah 85 dan skor minimum adalah 30 dengan rentang skor 55 .

Adapun skor peserta didik dalam siklus I, diperoleh distribusi frekuensi dan persentase skor hasil belajar Biologi peserta didik yang dapat dilihat pada tabel 7 berikut ini:

Tabel 7 Distribusi frekuensi dan presentase skor hasil belajar peserta didik Kelas X SMA Negeri 9 Bulukumba pada siklus 1

\begin{tabular}{cccc}
\hline $\begin{array}{c}\text { Interval } \\
\text { nilai }\end{array}$ & Kategori & Frekuensi & Presentase \\
\hline$<55$ & Sangat & 8 & 38,09 \\
$55-65$ & Rendah & 4 & 19,04 \\
$66-79$ & Rendah & 8 & 38,09 \\
$80-89$ & Sedang & 1 & 4,76 \\
$90-100$ & Tinggi & 0 & 0,00 \\
& Sangat & & \\
\hline & Tinggi & & 100,00 \\
\hline
\end{tabular}

Sumber: Hasil Analisi Lampiran E.1

Gambaran belajar peserta didik Kelas X SMA Negeri 9 Bulukumba pada siklus 1 dalam kategori sangat rendah sebanyak 8 peserta didik dengan presentase 38,09 persen, dalam kategori rendah sebanyak 4 peserta didik dengan presentase 19,04 persen, dalam kategori sedang sebanyak 8 orang dengan presentase 38,09 persen, dalam kategori tinggil orang sedangkan dalam kategori sangat tinggi tidak ada peserta didik yang mencapai kategori tersebut.

Deskripsi secara kuantitatif ketuntasan belajar Biologi peserta didik setelah pemberian tindakan dapat dilihat pada tabel 8 berikut ini:

Tabel 8 Deskripsi dan presentase skor hasil belajar peserta didik Kelas X SMA Negeri 9 Bulukumba pada siklus 1

\begin{tabular}{cccc}
\hline Skor & Kategori & Frekuensi & Persentase\% \\
\hline \multirow{2}{*}{$0-69$} & $\begin{array}{c}\text { Tidak } \\
\text { tuntas }\end{array}$ & 11 & 52,38 \\
$70-100$ & Tuntas & 10 & 47,61 \\
\hline \multicolumn{2}{c}{ Jumlah } & 21 & 100,00
\end{tabular}

Sumber: hasil Analisis Lampiran E.1

Pada tabel diatas dapat diketahui bahwa sebanyak 52 persen atau 11orang dari 21 peserta didik yang mencapai nilai tidak tuntas. Sedangkan yang tuntas hanya 10 orang atau 47,61 persen, karena masih banyak peseta didik yang tidak mencapai nilai ketuntasan minimal maka selanjutnya akan dilanjutkan pada siklus II untuk mengurangi peserta didik yang mencapai nilai ketuntasan minimum.

\section{4) Tahap Refleksi Siklus 1}

Setelah tahap perencanaan, pelakasanaan tindakan dan observasi serta evaluasi dan selanjutnya dilakukan tahap refleksi. Berdasarkan hasil observasi dan evaluasi diperoleh informasi bahwa masih ada peserta didik yang melakukan kegiatan lain pada saat jam pelajaran karena peserta didik masih kurang terbiasa dengan model pembelajaran yang digunakan. Model pembelajaran ini masih asing bagi peserta didik mengingat selama ini pembelajaran yang dilakukan oleh pendidik bersifat langsung. Setelah beberapa pertemuan dengan menggunakan model pembelajaran TAI peserta didik sudah mulai dengan pembelajaran yang dilakukan atau diterapkan. 
Pada awal siklus 1 keberanian untuk berpendapat masih sangat kurang, kemampuan untuk bertanya juga masih kurang dan peserta didik cenderung takut untuk menjawab pertanyaan maupun pertanya mengenai materi yang belum dimengerti, dalam siklus 1 juga peserta didik masih kurang aktif dalam kerja kelompok dan cendung melakukan kegiatan lain.

Pertemuan siklus 1 dalam pembagian kelompok peneliti sedikit mengalami kesulitan dalam pengelolaan kelas. Peserta didik banyak yang tidak setuju dengan kelompok yang telah dibentuk dan ditentukan oleh peneliti, karena ada peserta didik cenderung tidak mau bekerja sama dengan peserta didik yang lain dan memilih teman dekatnya untuk dijadikan teman kelompoknya. Setelah diberikan pengarahan dan pemahaman oleh peneliti bahwa kelompok yang dibentuk berdasarkan hasil tes awal yang diberikan oleh peserta didik pada pertemuan awal, sehingga peserta didik bergabung dengan teman kelompoknya yang telah dibentuk tersebut. Selain itu masih banyak peserta didik yang hanya menunggu jawaban dari temannya tanpa berusaha untuk menjawab pertanyaan yang diberikan, sehingga peneliti mengarahka untuk mengerjakan tugas yang diberikan tanpa menunggu bantuan dari temannya. Akibat dari hasil tersebut, proses belajar mengajar dan pemberian tugas belum mencapai peningakatan sesuai dengan yang diharapkan.

Dari hasil tindakan siklus 1 yang diberikan, peserta didik yang telah mencapai target sesuai dengan KKM sebanyak 10 orang dan 11 orang yang belum mencapai nilai KKM. Berdasarkan analisis diatas maka pendidik dan peneliti memutuskan untuk melanjutkan pada tindakan siklus II dengan proses yang hampir sama dengan Siklus 1 .

\section{a. Data Tindakan Siklus II \\ 1) Tahap Perencanaan Tindakan Siklus II}

Hasil dari refleksi pada tindakan siklus 1 peserta didik belum mencapai hasil yang diharapkan. Oleh karena itu, peneliti merancang kembali rencana pelaksanaan pembelajaran sebagai lanjutan materi dari siklus I dengan memperhatikan masalah yang muncul pada pertemuan siklus 1 yang telah dilaksanakan. Perencanaan dilanjutkan dengan membuat lembar observasi dan tes hasil belajar. Pada tindakan siklus II peneliti harus memberikan motivasi kepada peserta didik untuk belajar dengan memberikan pertanyaan kepada peserta didik sebelum memulai pelajaran, bersikap lebih tegas dan lebih mengontor kelas.

\section{2) Tahap Pelaksanaan Siklus II}

Pelaksanaan tindakan pada siklus II berlangsung selama 2 kali petemuan, dalam satu pertemuan masing-masing waktunya $2 \mathrm{x}$ 45 menit. Proses pembelajaran berlangsung dalam tiga tahapan kegiatan yang sama dengan pelaksanaan Siklus I yaitu: 1) kegiatan awal, 2) kegiatan Inti, 3) kegiatan Akhir.

1) Kegiatan Awal

Kegiatan awal sebelum memulai pelajaran yaitu ketua kelas meyiapkan dan memimpin untuk berdoa bersama. Kemudian peneliti mengabsen peserta didik dan tidak lupa untuk memberikan motivasi kepada peserta didik agar peserta didik semangat dalam belajar. Selanjutkan peneliti menyampaikan materi yang akan dipelajari serta tujuan pembelajaran yang hendak dicapai.

2) Kegiatan Inti

Mengingat hasil yang diperoleh pada siklus 1 masih tidak sesuai dengan apa yang diharapkan, maka tindakan yang dilakukan pada siklus II ini harus diperbaiki atau diadakan perubahan. Sesuai dengan langkah model pembelajaran TAI, langka pertama peneliti menjelaskan materi pembelajaran secara singkat sebelum melakukan kerja kelompok. Kelompok pada siklus II sama dengan siklus 1 yang terdapat pada lampiran C.2, peserta didik sudah tidak keberatan lagi dengan kelompok yang telah dibentuk karena sudah terbiasa dengan anggota kelompoknya. 
Selanjutnya, setiap peserta didik atau setiap anggota kelompok mengerjakan soal LKS yang telah dibagikan. Selama peserta didik melaksanakan kerja kelompok peneliti juga mengamati secara individu dan pengamatan secara kelompok. Dalam pelaksanaan Siklus II ini peserta didik sudah aktif dalam kerja kelompok dan aktivitas peserta didik dapat ditingkatakan. Peneliti lebih memperketat pengawasan kepada peserta didik yang melakukan kegiatan lain yang kurang positif seperti ribut, menyontek dan sebagainya sehingga suasana kelas lebih kondusif.

Pelaksanaan pembelajaran dengan menggunakan model pembelajaran TAI, agar tujuan pembelajaran dapat tercapai. Setelah peserta didik melakukan kerja kelompok, peneliti meminta perwakilan dari setiap kelompok untuk mempresentasikan hasil kerja kelompoknya. Dalam meningkatkan prestasi belajar peserta didik peneliti memberikan penghargaan kepada kelompok yang berhasil menyelesaikan tugas yang diberikan, peserta didik yang meberikan tanggapan. Penghargaan yang diberikan berupa tepuk tangan dan acungan jempol dan lain-lain.

\section{3) Kegiatan Akhir}

Pada kegiatan akhir pembelajaran peneliti bersama peserta didik menyimpulkan pembelajaran. Peneliti membimbing peserta didik membuat rangkuman pembelajaran dan memberikan penguatan dan motvasi kepada peserta didik. Mengakhiri rangkaian pembelajaran ketua kelas menyiapkan dan memberikan salam serta ketua kelas memimpin temannya untuk berdoa bersama.

\section{3) Tahap Observasi dan Evaluasi Siklus II}

\section{(1) Observasi}

Aktivitas peserta didik dalam pelaksanaan siklus II pertemuan pertama selama proses belajar mengajar berlangsung terhadap tindakan yang dilakukan dengan menggunakan lembar observas aktivitas peserta didik dapat dilihat pada tabel dibawah ini:
Tabel 9 Perkembangan aktivitas peserta didik kelas X pada siklus II

\begin{tabular}{|c|c|c|}
\hline No. & Komponen yang diamati & Pertemuan 1 \\
\hline 1 & $\begin{array}{l}\text { Peserta didik yang hadir } \\
\text { dalam proses belajar } \\
\text { mengajar }\end{array}$ & 21 \\
\hline 2 & $\begin{array}{l}\text { Peserta didik yang yang } \\
\text { mengajukan pertanyaan }\end{array}$ & 4 \\
\hline 3 & $\begin{array}{l}\text { Peserta didik yang aktif } \\
\text { bekerja sama dalam } \\
\text { kelompoknya }\end{array}$ & 17 \\
\hline 4 & $\begin{array}{l}\text { Peserta didik yang merespon } \\
\text { pertanyaan yang diajukan } \\
\text { pendidik/peneliti }\end{array}$ & 5 \\
\hline 5 & $\begin{array}{l}\text { Peserta didik yang } \\
\text { mengerjakan tugas individu }\end{array}$ & 21 \\
\hline 6 & $\begin{array}{l}\text { Peserta didik yang memiliki } \\
\text { kemampuan menyimpulkan } \\
\text { materi pelajaran }\end{array}$ & 4 \\
\hline 7 & $\begin{array}{l}\text { Peserta didik yang } \\
\text { mengemukakan pendapat }\end{array}$ & 6 \\
\hline 8 & $\begin{array}{l}\text { Peserta didik yang } \\
\text { melakukan kegiatan lain } \\
\text { seperti ribut, bermain dan } \\
\text { lain-lan }\end{array}$ & 4 \\
\hline
\end{tabular}

Sumber: Hasil Analisis Lampiran C.4

Jumlah peserta didik yang hadir dalam proses belajar mengajar pada pertemuan pertama sebanyak 21 orang. Peserta didik yang mengajukan pertanyaan pada pertemuan pertama hanya 4 orang. Peserta didik yang aktif bekerja sama dalam kelompok diskusi sebanyak 17 orang. Peserta didik yang merespon pertanyaan yang diajukan oleh pendidik pertemuan pertama sebanyak 5 orang. Adapun peserta didik yang aktif mengerjakan tugas individu pertemuan pertama sebanyak 21 orang.Adapun peserta didik yang memiliki kemampuan menyimpulkan materi pembelajaran sebanyak 4 orang. Sedangkan peserta didik yang mengemukakan pendapat pada pertemuan pertama pada siklus II sebanyak 6 peserta didik, disebabkan peserta didik sudah tidak canggung mengemukakan pendapat karena peserta didik dan sudah akrab dengan pendidik dan serta sudah memahami model pembelajaran TAI.Adapun peserta didik yang melakukan kegiatan lain seperti ribut, bermanin dan kegiatan lainnya 
mengalami penurunan dalam siklus II yakni sebanyak 4 orang.

Adapun aktivitas pendidik dalam siklus II pertemuan pertama dapat dilihat dalam tabel dibawah ini:

Tabel 10 Perkembangan aktivitas pendidik kelas Kelas X SMA Negeri 9 Bulukumba pada mata pelajaran Biologisiklus II.

\begin{tabular}{|c|c|c|}
\hline No & $\begin{array}{c}\text { Komponen yang } \\
\text { diamati }\end{array}$ & Pertemuan 1 \\
\hline 1 & Apersepsi & Baik \\
\hline 2 & Penjelasan materi & Baik \\
\hline 3 & $\begin{array}{l}\text { Penjelasan model } \\
\text { TAI }\end{array}$ & Baik \\
\hline 4 & $\begin{array}{l}\text { Teknik pembagian } \\
\text { kelompok }\end{array}$ & Baik \\
\hline 5 & $\begin{array}{l}\text { Pengelolaan } \\
\text { kegiatan diskusi }\end{array}$ & Baik \\
\hline 6 & $\begin{array}{l}\text { Pemberian } \\
\text { pertanyaan atau kuis }\end{array}$ & Baik \\
\hline 7 & $\begin{array}{l}\text { Kemampuan } \\
\text { melakukan evaluasi }\end{array}$ & Cukup \\
\hline 8 & $\begin{array}{l}\text { Memberikan } \\
\text { penghargaan } \\
\text { individu atau } \\
\text { kelompok }\end{array}$ & Baik \\
\hline 9 & $\begin{array}{l}\text { Menyimpulkan } \\
\text { materi pelajaran }\end{array}$ & Cukup \\
\hline 10 & Menutup pelajaran & Baik \\
\hline & Presentase & 93,33 \\
\hline
\end{tabular}

Sumber: Hasil AnalisisLampiran C.5

Pada pertemuan kedua apersepsi pendidik berada pada taraf baik yang diamati oleh pengamat hal ini disebabkan karena peneliti sudah dapat beradaptasi dengan baik dalam kelas. Penjelasan materi pelajaran dan model pembelajaran TAI masih sama dalam pertemuan pertama yaitu sudah baik dan peserta didik yang ribut dan melakukan kegiatan lain sudah mengalami penurunan dari siklus I. Cara pendidik membagi kelompok masih sama seperti siklus 1 yaitu dengan cara heterogen dalam siklus pertama ini dibentuk 4 kelompok, dimana dalam satu kelompok terdiri dari 5-6 orang.

Dalam pengelolaan kegiatan diskusi pendidik/peneliti sudah baik dalam mengarahkan jalannya proses diskusi. Setelah peserta didik bergabung dengan anggota kelompoknya pendidik membagikan lembar kerja yang berisi pertanyaan yang akan didiskusikan oleh setiap kelompok. Peneliti mengawasi jalannya diskusi. Pendidik meluruskan jawaban-jawaban peserta didik yang belum sempurna dan sebelum menutup pelajaran pendidik menyimpulkan materi diskusi pada saat itu.

Berdasarkan hasil pengamatan aktivitas pendidik pada siklus II mengalami peningkatan dari siklus I yaitu dengan presentase 93,33 persen dikarena pendidik sudah mengelolah pembelajaran dengan baik.

(2) Evaluasi

Pada akhir siklus II dilakukan tes hasil belajar yang berbentuk essai yang terdiri dari 5 nomor, adapun analisis deskriptif skor perolehan hasil belajarpeserta didik setelah penerapan model pembelajaran TAI dapat dilihat pada tabel berikut:

Tabel 11 Deskriptif skor hasil belajar Biologi peserta didik pada Siklus II

\begin{tabular}{cc}
\hline Statistik & Nilai statistik \\
\hline Subjek penelitian & 21 \\
Skor ideal & 100 \\
Skor rata-rata & 80 \\
Rentang skor & 35 \\
Skor maksimum & 95 \\
Skor minimum & 65 \\
\hline
\end{tabular}

Sumber : Hasil Analisis Lampiran E.1

Pada tabel diatas menunjukkan bahwa, skor rata-rata yang dicapai adalah 80 persen dengan skor ideal 100. Adapun skor maksimal yang dicapai pada siklus I adalah 95 dan skor minimum adalah 65 dengan rentang skor 35 .

Adapun skor peserta didik dalam siklus I, diperoleh distribusi frekuensi dan persentase skor hasil belajarBiologipeserta didik yang dapat dilihat pada tabel 4.12 berikut ini:

Tabel. 12 Presentase skor hasil belajar peserta didik Kelas X SMA Negeri 9 Bulukumba pada siklus II

\begin{tabular}{cccc}
\hline $\begin{array}{c}\text { Interval } \\
\text { nilai }\end{array}$ & Kategori & Frekuensi & Presentase \\
\hline$<55$ & Sangat & 0 & 0 \\
$55-65$ & Rendah & 3 & 14,28 \\
$66-79$ & Rendah & 4 & 19,04 \\
\hline
\end{tabular}




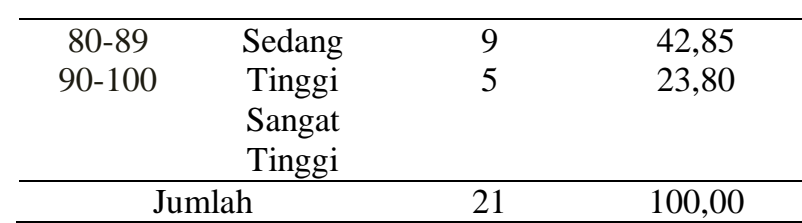

Sumber: Hasil Analisi lampiran E.1

Gambaran belajar peserta didik kelas

$\mathrm{IX}_{5}$ Kelas X SMA Negeri 9 Bulukumba pada siklus II dalam kategori sangat rendah sebanyak 0 peserta didik dengan presentase 0 persen, pada interval 55-65 sebanyak 4 peserta didik dalam kategori rendah tersebut, dalam kategori sedang sebanyak 3 orang, dalam kategori tinggi 9 orang sedangkan dalam kategori sangat tinggi sebanyak 5 orang dengan presentase 23,80 persen.

Deskripsi secara kuantitatif ketuntasan belajar Biologi peserta didik setelah pemberian tindakan dapat dilihat pada tabel 4.13 berikut ini:

Tabel. 13 Deskripsi dan presentase skor hasil belajar peserta didik Kelas X SMA Negeri 9 Bulukumba pada Siklus II

\begin{tabular}{|c|c|c|c|}
\hline \multicolumn{3}{|c|}{ Negeri 9 Bulukumba } & pada Siklus II \\
\hline Skor & Kategori & Frekuensi & Persentase \\
\hline $0-69$ & $\begin{array}{l}\text { Tidak } \\
\text { tuntas }\end{array}$ & 3 & 14,28 \\
\hline $70-100$ & Tuntas & 18 & 85,71 \\
\hline & & 21 & 100,00 \\
\hline
\end{tabular}

Sumber: hasil Analisis Lampiran E.1

Pada tabel diatas dapat diketahui bahwa sebanyak 85 persen atau 18 orang dari 21 peserta didik yang mencapai nilai ketuntasan. Sedangkan yang tidak mencapai nilai ketuntasan sebanyak 14,28 persen atau 3 orang dari 21 persen peserta didik, karena sudah banyak peseta didik yang mencapai nilai ketuntasan minimal maka tidak dilanjutnya akan ke siklus selanjutnya.

\section{4) Tahap Refleksi Siklus II}

Pembelajaran siklus II dilaksanakan untuk meningkatkan hasil belajar peserta didik. Peserta didik sudah terbiasa dengan kegiatan pembelajaran yang dilakukan dengan mengerjakan tugas individu kemudian mendiskusikan dengan teman kelompoknya.

Pembelajaran dengan menggunakan model pembelajaran kooperatif tipe Team Assisted Individualization (TAI) diterapkan dalam tindakan siklus II dan siklus I, peneliti telah melaksanakan tugas mulai dari kegiatan awal sampai kegiatan akhir dengan prestasi belajar peserta didik yang cukup baik.

Model pembelajaran TAI dengan perpaduan antara pembelajaran individual dan pembelajaran kelompok sangat membantu peserta didik untuk mencapai hasil belajar yang memuaskan. Dalam pembelajaranBiologitidak hanya peserta didik yang memiliki kemampuan akademis sedang yang aktif dalam proses pembelajaran, bahkan peserta didik yang memiliki kemampuan akademis yang rendah juga terlibat aktif dalam pembelajaran Biologi. Peserta didik yang memiliki kemampuan akademis yang rendah sering bertanya kepada temannya yang mengerti atau dapat mengerjakan tugas yang telah diberikan. Dan peneliti memberikan bimbingan kepada peserta didik yang mengalami kesulitan dalam belajar, kegiatan ini sangat membantu peserta didik yang kurang memahami tugas yang diberikan sehingga dapat mencapai nilai ketuntasan.

Dari hasil tes yang berikan kepada peserta didik pada evaluasi siklus II, rata-rata peserta didik telah mencapai nilai KKM. Semua peserta didik telah mencapai target bahkan banyak peserta didik yang melewati target ketuntasan nilai KKM. Hasil evaluasi siklus II dapat lihat dalam lampiran E.I dari hasil tersebut dapat dikatakan bahwa penelitian dengan menggunakan model pembelajaran TAI dalam pembelajaran Biologi dianggap telah berhasil dan selesai.

\section{b. Penerapan Model Pembelajaran Team Assisted Individualization (TAI) dalam Pembelajaran Biologi}

Berdasarkan hasil angket penerapan model TAI dan hasil analisis data sebagaimana yang tercantum dalam lampiran, berikut distribusi frekuensi dan persentase skor penerapan model kooperati tipe TAI dalam pelajaran Biologi peserta didik pada tabel 4.14 berikut : 
Tabel 14 Data Distribusi Tanggapan Penerapan Model Team Assisted Individualization (TAI)

\begin{tabular}{cccc}
\multicolumn{4}{c}{ Individualization (TAI) } \\
$\begin{array}{c}\text { Interval } \\
\text { nilai }\end{array}$ & Kategori & Frekuensi & Presentase \\
\hline$<55$ & Sangat & 2 & 9,52 \\
$55-65$ & Rendah & - & 00,00 \\
$66-79$ & Rendah & 4 & 19,04 \\
$80-89$ & Sedang & 10 & 47,61 \\
$90-100$ & Tinggi & 5 & 23,80 \\
& Sangat & & \\
& Tinggi & & 100,00 \\
\hline Jumlah & & 21 &
\end{tabular}

Sumber : Lampiran C.8 Angket Penerapan Model TAI

Distribusi memperlihatkan bahwa dari

21 orang peserta didik yang telah mengisi angket tentang tanggapan penerapan model TAI, terdapat 4 orang peserta didik dengan persentase 19,04 persen berada pada kategori sedang, 10 orang peserta didik dengan persentase 47,61 persen berada pada kategori tinggi, 5 orang peserta didik dengan persentase 23,80 persen berada pada kategori sangat tinggi, dengan skor rata-rata berada pada kategori baik.

Sebelum penerapan model pembelajaran kooperatif tipe TAI, hasil belajar peserta didik masih kurang atau peserta didik masih banyak yang belum mencapai nilai ketuntasan minimum yang ditetapkan. Hal tersebut diketahui setelah pendidik melaksanakan tes awal untuk mengetahu rata-rata belajar peserta didik

Berdasarkan hasil penelitian yang dilakukan oleh Slavin (2007:33) menyatkan bahwa pembelajaran kooperatif: penggunaan pembelajaraan kooperatif dapat meningkatkan prestasi maupun hasil belajar siswa selakaligus dapat meningkatkan hubungan sosial, menumbuhkan sikap toleransi, dan menghargai pendapat orang lain, (2) pembelajaran kooperatif dapat memenuhi kebutuhan sisiwa berpikir kritis, memecahkan masalah, dan mengintegrasikan pengetahuan dengan pengalaman. Dengan tersebut, strategi pembelajaran kooperatif diharapkan mampu meningkatkan kualitas pembelajaran.
Dari hasil penelitian yang dilakukan oleh Slavin tersebut, maka model pembelajaran kooperati dapat meningkatkan kualitas pembelajaran. Salah satu model pembelajaraan kooperatif tersebut adalah model pembelajaraan kooperatif tipe TAI. Model pembelajaraan TAI adalah model yang menggombinasikan antara pembelajaraan individu dengan pembelajaran kolompok.

Berdasarkan hasil rekapitulasi hasil belajar peserta didik Kelas X SMA Negeri 9 Bulukumba dan penelitian terdahulu, dapat disimpulkan bahwa pembelajaran kooperatif tipe TAI dapat meningkatkan hasil belajar peserta didik.

\section{Pembahasan}

Dalam pembahasan ini diuraikan hasil penelitian dengan menggunakan model pembelajaran Team Assisted Individualization (TAI) dalam mata pelajaranBiologipada materi kebijakan pemerintah dibidang Biologi bagi peserta didik Kelas X SMA Negeri 9 Bulukumba.

\section{Gambaran Situasi Dalam Kelas Pembelajaran Biologi Sebelum Penerapan Model Pembelajaran Kooperatif Tipe Team Assisted Individualization (TAI)}

Sebelum penerapan model pembelajaran kooperatif tipe Team Assistend Individualization (TAI), terlebih dahulu peneliti megamati aktivitas yang dilakukan oleh pendidik. Berdasarkan hasil pengamatan peneliti terhadap pendidik sebelum peneliti melakukan tindakan yaitu terdapat beberapa hal-hal pada aspek penjelasan materi peneliti menilai pendidik cukup dalam menjelaskan materi pembelajaran penerapan kebiasaan bertanya dinilai kurang karena pendidik hanya memberikan penjelasan materi tanpa diimbangi dengan memberikan kesempatan bertanya kepada peserta didik dan tidak mengadakan tanya jawab. Aspek dari segi teknik pemberian pembelajaran juga dinilai kurang dikarenakan pendidik hanya 
mejelaskan materi tanpa melibatkan peserta didik secara aktif dalam pembelajaran.

Sebelum penerapan model pembelajaran kooperatif tipe Team Assistend Individualization (TAI), terlebih dahulu peneliti mengadakan pre-test untuk mengetahui nilai rata -rata belajar peserta didik dengan memberikan 5 soal yang terdapat dalam lampiran B.3 Pada tes awal peserta didik yang hadir sebanyak 19 orang dari 21 jumlah keselurahan peserta didik.

Dari hasil tes awal tersebut didapatkan hasil bahwa, sebanyak 5 peserta didik yang tuntas yang lainnya dalam kategori sangat rendah. Ini membuktikan bahwa masih sangat rendah hasil pembelajaran Biologi bagi peserta didik Kelas X SMA Negeri 9 Bulukumba . Berdasarkan dari hasil pengamatan dari pendidik dan peserta didik sebelum diterapkan model pembelajaran TAI, masih kurang efektif dalam proses pelaksanaan pembelajaran disebabkan karena masih banyak peserta didik yang tidak mencapai Standar Ketuntasan Minimum (KKM), maka perlu diadakan perubahan dalam proses pembelajaran salah satunya adalah dengan menggunakan model pembelajaran kooperatif tipe TAI diharapkan dapat memotivasi peserta didik dan meningkatkan keefektifan dalam proses belajar mengajar.

2. Gambaran Aktivitas Pendidik Dalam Implementasi Model Pembelajaran Kooperatif Tipe Team Assisted Individualization (TAI)

Aktivitas pendidik dalam proses pelaksanaan pembelajaraan kooperatif tipe Team Assisted Individualization (TAI), pada siklus I pendidik/peneliti mengalami kesulitan karena pendidik belum begitu akrab dengan peserta didik. Pendidik juga masih sedikit kesusahan dalam mengelolah kelas, seperti pada saat pendidik menjelaskan materi pembelajaran Biologi masih banyak peserta didik yang ribut dalam kelas, bercerita dengan teman sebangkunnya dan bahkan ada peserta didik yang mengantuk dalam kelas tetapi pendidik dapat mengatasi hal-hal tersebut dengan cara menegur peserta didik yang ribut dalam kelas atau pendidik mengajukan pertanyaan kepada peserta didik mengenai materi yang diajarkan agar peserta didik dapat berpikir tentang jawaban pertanyaan tersebut sehingga peserta didik kembali fokus dalam pembelajaran. Pendidik menjelaskan model pembelajaran yang akan dilakukan yaitu model pembelajaran kooperatif tipe Team Assisted Individualization (TAI), pada siklus I pendidik pembagi kelompok secara heterogen yaitu sebanyak 4 kelompok, dalam satu kelompok terdapat 5-6 peserta didik. Dalam siklus II pendidik sudah tidak mengalami kesulitan dan dapat mengelolah kelas dengan cukup baik disebabkan karena pendidik sudah akrab dengan situasi belajar peserta didik dan sudah mulai mengetahui karakter dari peserta didik tersebut. Pembagian kelompok pada siklus II sama dengan siklus I ini dimaksudkan agar peserta didik akrab dengan teman kelompoknya. Setelah peserta didik bergabung dengan kelompoknya kemudian diberikan LKS dan harus dikerjakan secara individu terlebih dahulu kemudian didiskusikan dengan anggota kelompok yang lainnnya. Hal tersebut dilakukan karena menggunakan model pembelajaran kooperatif tipe TAI yaitu model pembelajaran dengan mengkombinasikan antara pembelajaran individu dengan pembelajaran kelompok.

Berdasarkan hasil pengamatan aktivitas pendidik dapat disimpulkan bahwa pada siklus1 memperoleh skor rata-rata yaitu 62,9 persen Sedangkan pada siklus II mengalami peningkatan yaitu 80 persen.

\section{Gambaran Aktivitas Peserta Didik dalam Implementasi Model Pembelajaran Kooperatif Tipe Team Assisted Individualization (TAI) Dalam Pembejaran Biologi \\ Dalam pelaksanaan pembelajaraaan} Biologi dengan menggunakan model pembelajaran kooperatif tipe Team Assisted 
Individualization (TAI). Dalam bagian ini akan dibahas aktiviatas peserta didik dalam kegiatan pembelajaran yang mencakup antusias peserta didik dalam mengikuti pembelajaran, bagaimana interaksi peserta didik dengan pendidik dan antara peserta didik dari siklus I ke siklus II.

Tercatat sejumlah perubahan yang terjadi pada aktivias peserta didik yang diperoleh dari lembar observasi pada setiap pertemuan. Pada pelaksanaan pembelajaran ini dengan menggunakan model pembelajaran TAI mendorong peserta didik untuk belajar dan memperhatikan pelajaran, peserta didik pada siklus I cukup baik ini dibuktikan pada pertemuan I siklus I peserta didik yang hadir sebanyak 19 orang dari jumlah 21 keseluruhan peserta didik. Pada siklus I peserta didik dibagi dalam 4 kelompok. Rata-rata peserta didik yang mengajukan pertanyaan siklus 1 pertemuan I, yaitu 2 orang dalam pertemuan II yaitu 3 orang. Pada siklus II Rata-rata peserta didik yang mengajukan pertanyaan pada siklus II sebesar 4 orang. Rata-rata peserta didik yang aktif berkerja sama dalam kelompoknya pada siklus 1 yaitu dalam pertemuan I yaitu, 7 orang pertemuan II sebanyak 12 orang. pada siklus II yaitu 17 orang .

Rata-rata peserta didik yang merespon pertanyaan yang diajukan oleh pendidik pada siklus 1 yaitu dalam pertemuan I yaitu, 2 orang pertemuan II sebanyak 3 orang. pada siklus II Rata-rata peserta didik yang merespon pertanyaan yang diajukan oleh pendidik yaitu 5 orang

Rata-rata peserta didik yang mengerjakan tugas individu pada siklus 1 yaitu dalam pertemuan I yaitu, 18 orang pertemuan II sebanyak 20 orang. Pada siklus II Rata-rata peserta didik yang mengerjakan tugas individu pertemuan yaitu 21 orang.

Rata-rata peserta didik yang memiliki kemampuan menyimpulkan materi pembelajaran pada siklus 1 yaitu dalam pertemuan I yaitu, 1 orang pertemuan II sebanyak 3 orang Dalam siklus II Rata-rata peserta didik yang memiliki kemampuan menyimpulkan materi pembelajaran yaitu 4 orang.

Rata-rata peserta didik mengemukakan pendapat dalam pembelajaran pada siklus 1 yaitu dalam pertemuan I yaitu 2 0rang pertemuan II sebanyak 4 orang. pada siklus II Rata-rata peserta didik mengemukakan pendapat pembelajaran siklus II yaitu 6 orang.

Rata-rata peserta didik yang melakukan kegiatan lain seprti ribut, bermain dan lainlain yaitu materi pembelajaran pada siklus 1 yaitu dalam pertemuan I yaitu, 11 orang pertemuan II yaitu 8 orang . pada siklus II Rata-rata peserta didik yang melakukan kegiatan lain seperti ribut, bermain dan lainlain yaitu 17 persen. Dari data yang diperoleh dapat disimpulkan bahwa aktivitas peserta didik mengalami peningkatan dari siklus I ke Siklus II.

Berdasarkan data yang diperoleh maka pembelajaran dengan menggunakan model pembelajaran kooperatif tipe TAI, maka dapat disimpulkan bahwa mengalami peningkatan dari Siklus I ke Siklus II.

4. Gambaran Peningkatan Hasil Belajar Biologi Peserta Didik pada Materi Kebijakan Pemerintah Dibidang Biologi Setelah Diimplementasikan Model Pembelajaran Kooperatif Tipe Team Assisted Individualization (TAI)

Dalam pelaksanaan pembelajaran dengan menggunakan model pembelajaran kooperati tipe Team Assisted Individualization (TAI), mendorong peserta didik untuk dapat meningkatkan hasil belajar dengan model pembelajaran perpaduan antara kerja individu dengan kerja kelompok. Pada akhir suklis I dan siklus II dilakukan tes hasil belajar yang berbentuk essay. Dari hasil belajar peserta didik diperoleh peresentase ketuntasan pada siklus I yaitu 47,61 persen yang mencapai ketuntasan pembelajaran, dan peserta didik yang tidak mencapai ketuntasan pada siklus I yaitu 52,83 persen. Ini disebabkan karena peserta didik masih 
kurang terbiasa dalam penerapan model pembelajaran kooperatif tipe TAI dan peserta didik masih kurang serius dalam proses pembelajaran.

Pada siklus II presentase ketuntasan peserta didik mengalami peningkatan yaitu 85,71 persen. Sedangkan peserta didik yang tidak mencapai ketuntasan belajar yaitu 14,28 mengalami penurunan peserta didik yang tidak mencapai ketuntasan belajar.

\section{Respon Peserta Didik Tentang Model Pembelajaran Kooperatif Tipe Team Assisted Individualization (TAI)}

Berdasarkan data yang diperoleh bahwa dari 21 orang peserta didik yang telah mengisi angket tentang tanggapan penerapan model TAI, terdapat 4 orang peserta didik dengan persentase 17,00 persen berada pada kategori sedang, 12 peserta didik dengan persentase 52,00 persen berada pada kategori tinggi, 5 orang dengan persentase 22,00 persen berada pada kategori sangat tinggi, dengan skor rata-rata 76,08 persen atau berada pada kategori baik.

Dari data yang diperoleh dapat disimpulkan bahwa model pembelajaran kooperatif tipe Team Assisted Individualization (TAI) dapat meningkatkan hasil belajar dan keaktifan peserta peserta didik dalam mengikuti pelajaran Biologi

Merujuk dari hasil penelitian terdahulu yaitu dilakukan oleh Wahyuningtiyas (2008). Penerapan model pembelajaran kooperatif tipe TAI (Team Assisted Individualization) untuk meningkatkan aktivitas dan hasil belajarBiologisiswa kelas IIA SMA Negeri 12 Sigosari Malang. Penelitian ini merupakan penelitian kualitatif dengan rancangan penelitian tindakan kelas yang dilaksanakan dalam lebih dari siklus. Model siklus yang digunakan adalah model Kemmis dan Taggert. Data aktivitas siswa dikumpulkan dengan teknik observasi sedangkan hasil belajar melalui tes disetiap akhir pertemuan. Nilai rata-rata siswa kelas IIA SMA Negeri 12 Singosari Kabupaten
Malang sebelum dilakukan pembelajaran dengan metode TAI masih belum mencapai Standzar Ketuntasan Minimum yang telah ditetapkan yaitu 75. Skor rata-rat aktivitas belajar siswa dalam mengikuti kegiatan pembelajaranBiologipada siklus 1 Penerapan Model TAI adalah 71 dan hasil belajar siswa yang talah tuntas belajar sebesar 65,7 persen (23 Siswa) dan yang belum tuntas belajar sebesar 34,3 persen (12 siswa). Jadi dapat disimpulkan belum mencapai standar ketuntasan klasikal sebesar 75 persen, hasil pada siklusn II untuk aktivitas siswa adalah 75 dan hasil belajar siklus II ini, terdapat 35 siswa yang sudah tuntas KKM sebesar 75 (100 Persen). Setelah dilakukan penerapan model TAI aktivitas dan hasil belajar siswa dengan mengalami peningkatan dari siklus I ke siklus II.

Berdasarkan hasil penelitian sebelumnya yang telah dilakukan dan berdasarkan hasil yng diperoleh peneliti dalam melakukan penelitian di Kelas X SMA Negeri 9 Bulukumba dengan menggunakan model pembelajaran kooperatif tipe TAI dapat disimpulkan bahwa pembelajaran Biologi dapat meningkatkan hasil belajar dan keaktifan peserta didik kelas.

\section{KESIMPULAN}

Berdasarkan hasil $r$
penservasi
pembelitianaran kooperatif tipe TAI serta
mengacu pada rumusan masalah dalam
penelitian ini yang dilaksanakan selama dua
siklus, maka peneliti memperoleh
kesimpulan dari hasil penelitian tindakan ini.
Adapun kesimpulan yang dimaksud dalam
penelitian ini adalah:
a. Meningkatnya aktivitas pendidik ditandai
setiap siklus diantaranya pada siklus1
pada pertemuan pertama memperoleh
skor rata-rata yaitu 50,85 persen pada
pertemuan kedua memperoleh skor
dengan rata-rata 62,9 persen. Sedangkan
pada siklus II mengalami peningkatan
yaitu 80 persen.


b. Meningkatnya aktivitas peserta didik pada setiap pertemuan dalam penerapan model pembelajaran kooperatif tipe TAI

c. Meningkatnya hasil belajar peserta didik dalam setiap siklus pembelajaran. Pada siklus I hasil belajar 62,9 persen sedangkan pada siklus II meningkat menjadi 80 persen

d. Dengan penerapan model pembelajaran kooperatif tipe TAI meningkatkan hasil belajar peserta didik.

\section{DAFTAR PUSTAKA}

Abdurrahman, M. (1999). Pendidikan Bagi Anak Berkesulitan Belajar. Jakarta: Penerbit Rineka Cipta.

Arikunto, Suharsimi. (2007). Penelitian Tindakan Kelas. Jakarta: Bumi Aksara

Azis, Irfan. (2013). Peningkatan Hasil Belajar Sosiologi Melalui Model Pemebelajaran CTL Pada Pokok Bahasan Perubahan Sosial Pada Siswa Kelas $10 \quad$ SMA Muhammasiyah Kalosi Kecamatan Alla Kabupaten Enrekang. Skipsi, Makassar Faklutas Keguruan Dan Ilmu Pendidikan UNISMUH

Daryanto. (2011). Penelitian Tindakan Kelas Dan Penelitian Tindakan Sekolah. Yogyakarta: Gava Media

Deliarnov. 2003. Perkembangan Pemikiran Ekonomi. Jakarta: PT. Raja Grafindo Persada..

Huzaifah. (2013). Model Pembelajaran Kooperatif Tipe TAI. Artkel Tersedia Padahttp://zaifbio.wordpress.com/201 3/05/20/model-pembelajaran-tipe-taiteam-assisted-individualization/.

Diakses pada tanggal 05 Februari 2014, 09:15 WITA.

Mardia. (2004). Peningkatan Pemahaman Biologi Melalui Pembelajaran Kooperatif Tipe Team Assisted Individualizaton (TAI) Pada Siswa
Kelas 114 Sltp Negeri Makassar. Skripsi. FMIPA.UNM. Makassar Mardiyatmo.(2010).BiologiSMA Kelas X, Jakarta: Yudhistira Dunia Buku Sekolah

Muharrikah Raiddah. (2011). Meningkatkan hasil belajar Biologi melalui pembelajaran koooperatif tipe Team Assisted Individulazation (TAI) pada Sisiwa Kelas VII $B_{2}$ SMP Islam Terpadu Wahdahislamaiyah Makassar. Skipsi.Makassar. FMIPA UNM.

Nurhadi. (2004). Kurikulum 2004. Jakarta: Gramedia Widia Sarana.

Purwanto. (2004). Prinsip Dan Teknik Evaluasi Pengajaran. Bandung: PT. Remaja Rosdakarya

Rustam, (2013). Model-model Pembelajaran Mengembangkan Profesionalisme

Guru. Jakarta: PT Raja Grafindo Persada

Sanjaya, Wina. (2008). Strategi Pembelajaran Berorientasi Standar Proses Pendidikan. Jakarta: Kencana Prenada Media Group.

Slavin E. Robert. (2007). Cooverative Learning Riset dan Praktik. Bandung: Nusa Media.

Sudijono Anas, (2011). Pengantar Evaluasi Pendidikan. Jakarta: PT Raja Grafindo Persada

Sugiyanto. (2004). Model-model Pembelajaran Inovatif. Surakarta: Panitia Sertifikasi.

Trianto. (2009). Mendesain Model Pembelajaran Inovatif-Progresif. Jakarta: Kencana Prenada Media Group. 